Tarbawy : Jurnal Pendidikan Islam

ISSN : 2407-4462 (Cetak), 2614-5812 (Elektronik)

Vol. 8, No. 2, 2021, Hal. 61-66

DOI: https://doi.org/10.32923/tarbawy.v8i2.1824

\title{
Karakteristik Dan Model Integrasi Ilmu Madrasah Ibtidaiyah
}

\author{
Nila $^{1}$, Khamim Zarkasih Putro ${ }^{2}$ \\ ${ }^{1}$ UIN Sunan Kalijaga Yogyakarta \\ ${ }^{2}$ UIN Sunan Kalijaga Yogyakarta
}

\section{Info Artikel :}

Diterima 17 September 2021

Direvisi 28 September, 2021

Dipublikasikan 21 oktober 2021

\section{Kata Kunci: \\ Integrasi Ilmu, \\ Model Integrasi Ilmu \\ Integrasi ilmu Islam}

\section{Keywords:}

Science Integration, Science Integration ModelIntegration of Islamic knowledge

\begin{abstract}
ABSTRAK
Tulisan ini menjelaskan tentang karakteristik dan model integrasi ilmu madrasah ibtidaiyah. Tujuan dari penelitian ini untuk mengetahui karakterstik dan model ilmu madrasah ibtidaiyah. Metode penelitian ini menggunakan literature research atau penelitian kepustakaan yang akan dianalisis dan disimpulkan. Dalam pengumpulan data penulis menggunakan studi pustaka yaitu penelitian yang dilakukan dengan cara menggunakan data-data yang berkaitan dengan karakterstik dan model integrasi ilmu madrasah ibtidaiyah denagn ilmu Islam dari buku-buku, jurnal, internet dan sumber lainnya yang relevan. Penelitian ini bersifat kualitatif yang lebih mengutamakan penggalian, penemuan, pembacaan, penjelasan dan penyampaian makna atau simbol data yang tersurat dan terserat dari data yang dikumpulkan. Hasil penelitian ini berupa :1) pengertian dari Madrasah Ibtidaiyah, 2) Karakteristik integrasi Ilmu madrasah Ibtidaiyah , 3) model integrasi ilmu madrasah ibtidaiyah dengan. Kesimpulan dari tulisan ini Polarisasi yang demikian tentu akan merugikan kehidupan manusia karena ilmu-ilmu yang dikembangkan berbagai model salah satu model purifikasi.Oleh karena itu, dibutuhkan sebuah lembaga pendidikan alternatif mengembangkan keilmuan secara integratif, yang dapat memadukan antara ilmu-ilmu umum dan ilmu agama
\end{abstract}

\section{ABSTRACT}

This paper describes the characteristics and models of the integration of madrasah ibtidaiyah knowledge. The purpose of this study was to determine the characteristics and models of madrasah ibtidaiyah science. This research method uses literature research or library research to be analyzed and concluded. In collecting data the author uses a literature study, namely research conducted by using data relating to the characteristics and models of integration of madrasah ibtidaiyah science with Islamic knowledge from books, journals, internet and other relevant sources. This research is qualitative in nature which prioritizes excavation, discovery, reading, explanation and delivery of the explicit and implied meanings or symbols of data from the data collected. The results of this study are: 1) understanding of Madrasah Ibtidaiyah, 2) Characteristics of the integration of Madrasah Ibtidaiyah with Islamic Sciences, 3) model of integration of madrasah Ibtidaiyah science with. The conclusion of this paper that such polarization will certainly harm human life because the sciences developed by various models are one of the purification models.

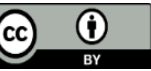

This is an open access article distributed under the Creative Commons Attribution License, which permits unrestricted use, distribution, and reproduction in any medium, provided the original work is properly cited. C2019 by author.

\author{
Koresponden: \\ Nila \\ Nila9771@gmail.com
}

\section{Pendahuluan}

Persoalan seputar integrasi ilmu belakangan ini sering didengarkan seiring dengan keinginan sebagian besar umat Islam untuk bangkit memperbaiki dan meningkatkan mutu pendidikan Islam yang selama ini masih tertinggal. Sampai saat ini masih ada kesenjangan antara keadaan yang seharusnya dengan kenyataannya. Implikasinya muncul ambivalensi dan disintegrasi ilmu yang menyebabkan dikotomi keilmuan dengan segala aspeknya. Dikotomi keilmuan terbelahnya ilmu agama dengan ilmu dunia, dikotomi antara wahyu dan alam, serta dikotomi antara wahyu dan aqal. Dikotomi yang pertama telah melanggengkan supremasi ilmu-ilmu agama yang berjalan secara monotonik, dikotomi kedua telah menyebabkan kemiskinan penilitian empiris dalam pendidikan Islam, serta dikotomi yang terakhir telah menjauhkan filsafat dari pendidikan Islam (Mas'ud,2003) 
Integrasi adalah konsep yang menegaskan bahwa integrasi keilmuan yang disasar bukanlah model meltingpot integration, di mana integrasi hanya dipahami hanya dari perspektif ruang tanpa subtansi. Integrasi yang dimaksud adalah model penyatuan yang antara satu dengan lainnya memiliki keterkaitan yang kuat sehingga tampil dalam satu kesatuan yang utuh. Hal ini perlu karena perkembangan ilmu pengetahuan yang dipelopori Barat sejak lima ratus tahun terakhir, dengan semangat modernisme dan sekulerisme telah menimbulkan pengkotak-kotakan ilmu dan mereduksi ilmu pada bagian tertentu saja.

Dampak lebih lanjut adalah terjadinya proses dehumanisasi dan pendangkalan iman manusia. Untuk menyatukan ilmu pengetahuan, harus berangkat dari pemahaman yang benar tentang sebab terjadinya dikotomi ilmu dibarat dan bagaimana paradigma yang diberikan Islam tentang ilmu pengetahuan. Pendidikan yang berlangsung dizaman modern ini lebih menekankan pada pengembangan disiplin ilmu dengan spesialisasi secara ketat, sehingga integrasi dan interkoneksi antar disiplin keilmuan menjadi hilang dan melahirkan dikotomi ilmu-ilmu agama di satu pihak dan kelompok ilmu-ilmu umum dipihak lain. Dikotomi ini menyebabkan terbentuknya perbedaan sikap di kalangan masyarakat. Sebagaimana karakteristik dan model integrasi ilmu madrasah ibtidaiyah dengn ilmu islam.

Penelitian ini bersifat kualitatif yang lebih mengutamakan penggalian, penemuan, pembacaan, penjelasan dan penyampaian makna atau simbol data yang tersurat dan terserat dari data yang dikumpulkan Penelitian ini adalah jenis penelitian kepustakaan. Mestika Zed menyebutkan bahwa penelitian kepustakaan adalah penelitian yang dilakukan dengan membaca karya-karya yang terkait dengan persoalan yang akan dikaji dan mencatat bagian penting yang ada hubungannya dengan topik bahasan. Moh. Nazir menjelaskan pula bahwa penelitian kepustakaan (library research) adalah suatu metode yang dipakai dengan penala'ahan buku-buku yang berhubungan dengan tema yang dibahas (M. Nazir, 2005).

Dalam pengumpulan data penulis menggunakan studi pustaka yaitu penelitian yang dilakukan dengan cara menggunakan data-data yang berkaitan dengan dasar-dasar pendidikan Islam dari buku-buku, jurnal, koran, internet dan sumber lainnya yang relevan

\section{Hasil dan Pembahasan}

\section{Pengertian Madrasah Ibtidaiyah}

Madrasah Ibtidaiyah adalah bagian dari pendidikan dasar formal dengan ciri keagamaan. Madrasah Ibtidaiyah merupakan lembaga pendidikan Islam yang lebih modern, yang memadukan antara pendidikan pesantren dan sekolah, yang materinya mengintegrasikan agama dan pengetahuan umum. Madrasah Ibtidaiyah sebagai lembaga pendidikan Islam berfungsi menghubungkan sistem lama dan sistem baru dengan jalan mempertahankan nilai-nilai lama yang masih baik dan dapat dipertahankan dan mengambil sesuatu yang baru dalam ilmu, teknologi, dan ekonomi yang bermanfaat bagi kehidupan umat Islam, sedangkan isi kurikulum madrasah pada umumnya sama dengan pendidikan di pesantren ditambah dengan ilmu- ilmu umum Untuk dapat mengimplementasi-kan program pendidikan karakter yang efektif.(Haedar Nashir, 2013).

Pelaksanaan pendidikan di Madrasah Ibtidaiyah (MI) dapat dilakukan dengan cara berikut ini. Mengintegrasikan ke setiap mata pelajaran. Mengintegrasikan ke setiap mata pelajaran bertujuan untuk memperkenalkan nilai-nilai pendidikan karakter di setiap mata pelajaran, sehingga menyadari akan pentingnya nilai-nilai tersebut dan penginternalisasian nilai-nilai ke dalam tingkah laku peserta didik sehari-hari melalui proses pembelajaran, baik yang berlangsung di dalam maupun di luar kelas. Selain untuk menjadikan peserta didik menguasai kompetensi (materi) yang ditargetkan, juga dirancang untuk menjadikan peserta didik mengenal, menyadari dan menginternalisasi nilai-nilai dan menjadikannya perilaku. Pengembangan Budaya Madrasah. Madrasah bertanggung jawab menanamkan pengetahuan-pengetahuan baru yang reformatif dan transformatif dalam membangun bangsa yang maju dan berkualitas. Madrasah juga bertanggungjawab mentransformasikan nilai-nilai luhur kepada siswa. Dengan demikian, peran madrasah sangat besar dalam menentukan arah dan orientasi bangsa ke depan. Budaya madrasah menjadi salah satu aspek yang berpengaruh terhadap perkembangan peserta didik. Suasana madrasah yang penuh kedisiplinan, kejujuran, kasih sayang akan menghasilkan karakter yang baik. Sama halnya dengan para pendidik, mereka akan mengajar dengan suasana damai, sehingga mendorong peningkatan mutu pembelajaran. 


\section{Karakteristik Integrasi Ilmu Madrasah Ibtidaiyah}

Sebagai bagian pendidikan dasar madrasah ibtidiayah memiliki posisi strategis dalam penanaman karakter dasar siswa yang akan dibawanya kelak hingga menuju dewasa. Teori psikologi menyimpulkan bahwa usia anak-anak adalah masa paling bagus dalam pembentukan karakter. Oleh karenanya menjadi penting untuk mengetahui konsep, metode dan hambatan serta bagaimana mengatasi hambatan pendidikan karakter di Madrasah Ibtidaiyah. Furqon Hidayatullah menyebutkan bahwa strategi penanaman karakter meliputi lima hal, yaitu 1) keteladanan, 2) penenaman kedisiplinan. 3) pembiasaan-pembudayaan, 4) menciptakan suasana kondusif, dan 5) integrasi dan internalisasi (Furqon 2011)

Pendidikan karakter bukan hanya tanggung jawab guru bidang studi tertentu, tetapi menjadi tugas seluruh komponen sekolah. Pembentukan karakter adalah bagian integral dari orientasi pendidikan Islam. Tujuannya adalah membentuk kepribadian seseorang agar berperilaku jujur, baik, bertanggung jawab, menghormati dan menghargai orang lain, adil tidak diskriminatif, pekerja keras dan karakter-karakter unggul lainnya. Agama Islam, mempunyai dua istilah yang menunjukkan penekanan mendasar pada aspek pembentukan karakter dalam pendidikan: yakni ta'dib dan tarbiyyah. Ta'dib berarti usaha untuk menciptakan situasi yang mendukung dan mendorong anak didik untuk berperilaku baik dan sopan sesuai yang diharapkan. Sementara tarbiyyah berarti merawat potensi-potensi baik yang ada pada diri manusia agar tumbuh dan berkembang. Seyogianya memenuhi beberapa prinsip dalam karakteristik pendidikan madrasah ibtidaiyah diantaranya, Komunitas madrasah mengembangkan dan meningkatkan nilai-nilai inti etika dan kinerja sebagai landasan karakter yang baik. Madrasah berusaha mendefinisikan karakter secara komprehensif, didalamnya mencakup berpikir, merasa, dan melakukan. Madrasah menggunakan pendekatan yang komprehensif, intensif, dan proaktif dalam pengembangan karakter. Madrasah menciptakan sebuah komunitas yang memiliki kepedulian yang tinggi.Madrasah menyediakan kesempatan yang luas bagi para siswa untuk melakukan berbagai tindakan moral. Madrasah menyediakan kurikulum akademik yang bermakna dan menantang, dapat menghargai dan menghormati seluruh peserta didik, mengembangkan karakter mereka dan berusaha membantu mereka untuk meraih berbagai kesuksesan. Madrasah mendorong siswa untuk memiliki motivasi diri yang kuat.Madrasah adalah komunitas belajar etis yang senantiasa berbagi tanggung jawab.

Madrasah mendorong kepemimpinan bersama yang memberikan dukungan penuh terhadap gagasan pendidikan karakter dalam jangka panjang. Madrasah melibatkan keluarga dan masyarakat sebagai mitra dalam upaya pembangunan karakter. Secara teratur, madrasah melakukan assessment terhadap budaya dan iklim sekolah, keberfungsian para staf sebagai pendidik karakter di sekolah, dan sejauh mana siswa dapat mewujudkan karakter yang baik dalam kehidupan sehari-hari.( Amirulah Syarbin, 2012. )

Dalam Pendidikan karakter di Madrasah Ibtidaiyah agar dapat mencapai pertumbuhan integral dan integrasi perlulah dipertimbangkan berbagai macam prinsip penggunaan metode pendidikan yang idealnya memuat nilai-nilai spiritual yaitu sebagai berikut:

1) Niat dan orientasi dalam pendidikan, yaitu untuk mendekatkan hubungan antara manusia dengan Allah dan sesama makhluk.

2) Keterpaduan antara domain kognitif (pikir), afektif (dzikir), dan psikomotorik (amal) guna mendapatkan kesejahteraan dan kebahagiaan hidup di dunia dan akhirat.

3) Bertumpu pada kebenaran, dalam arti materi yang disampaikan itu harus benar, disampaikan dengan cara yang benar, dan dengan dasar niat yang benar.

4) Berdasar pada nilai. Artinya, pendekaan dan metode pendidikan tetap berdasarkan pada nila-nilai etika dan moral (Akhlaqul Karimah).

5) Sesuai dengan kebutuhan peserta didik.

6) Memberikan kemudahan.

7) Berkesinambungan. Setelah menggunakan metode tertentu, seorang guru perlu memerhatikan letak kekurangan dan kelemahan metode yang digunakan.

8) Fleksibel dan dinamis. Dengan kelunturan dan kedinamisan metode tersebut, pemakaian metode tidak hanya monoton dengan satu macam metode. (Novan Ardy Wiyani dan Barnawi,2012) 


\section{Model Integrasi Ilmu Madrasah Dengan Ilmu Islam}

Dalam pelaksanaan pendidikan di sekolah, kurikulum menempati posisis penting. Secara definitif, kurikulum diartikan sebagai rencana program pengajaran atau pendidikan yang akan diberikan kepada anak didik. Berbeda dari anggapan umum, kurikulum sebenarnya meliputi rencana kegiatan ko- dan ekstrakurikuler, termasuk di dalamnya adalah filosofi pendidikan yang dianut oleh lembaga pendidikan tersebut. Dalam membangun kurikulum pendidikan Islam yang integralistik, Ibnu Khaldun menyatakan bahwa prinsip penyusunan kurikulum, diantaranya harus memperhatikan prinsip integritas (al-takamul). (Walidin:2017).

Hanna Djumhana Bastaman, seorang psikolog Muslim, mengemukakan bahwa ada beberapa bentuk pola integrasi keilmuan mi-an mulai dari bentuk yang paling superficial sampai dengan bentuk yang paling mendasar, diantara model tersebut model integrasi pada ilmu madrasah ibtidaiyah.

\section{a. Similarisasi}

Yaitu menyamakan begitu saja konsep-konsep sains dengan konsep-konsep yang berasal dari agama, padahal belum tentu sama. Misalnya, dalam psikologi, menganggap ruh sama dengan jiwa, atau al-nafs al-amarah, nafs al-lawwamah, dan nafs al muthmainnah dari alQur'an dianggap identik dengan konsep-konsep id, ego, dan super ego.

b. Paralelisasi

Yaitu menganggap paralel konsep yang berasal dari al-Qur'an dengan konsep yang berasal dari sains karena kemiripan konotasinya, tanpa mengidentikkan keduanya. Misalnya menganggap perang dunia III sejalan dengan kiamat, atau menjelaskan isra' mi' raj paralel dengan perjalanan ke ruang angkasa dengan menggunakan rumus fi- sika $\mathrm{s}=\mathrm{v} \times \mathrm{t}$ (jarak $=$ kecepatan $\mathrm{x}$ waktu), di mana faktor kecepatannya $=$ tak terhingga. Paralelisasi sering digunakan sebagai penjelasan ilmiah kebenaran ayat-ayat al-Qur'an dalam rangka menyebarkan syi'ar Islam kepada kelom- pok masyarakat terpelajar.

c. Komplementasi

Yaitu antara sains dan agama saling mengisi dan memperkuat satu sama lain, tetapi tetap mempertahankan eksistensi masing-masing. Misalnya manfaat puasa ramadhan (untuk kesehatan) dijelaskan dengan prinsip-prinsip dietary dari ilmu kedokteran. Atau kebijakan keluarga berencana didukung oleh ayat-ayat al-Qur'an dan al- Hadis Nabi Saw. Dalam hal ini tampaknya terjadi saling mengabsahkan/justifikasi antara sains dan agama.

\section{d. Komparasi}

Yaitu membandingkan konsep/teori sains dengan konsep/wawasan agama mengenai gejala-gejala yang sama. Misalnya teori motivasi dari psikologi dibandingkan dengan konsep motivasi yang dijabarkan dalam ayat-ayat al-qur'an

e. Induktifikasi

Yaitu asumsi-asumsi dasar dari teori-teori ilmiah yang didukung oleh temuan-temuan empirik dilanjutkan pemikirannya secara teoritis abstrak ke arah pemikiran metafisik/goib kemudian dihubungkan dengan prinsip-prinsip agama dan al-Qur'an mengenai hal tersebut. Teori adanya "sumber gerak yang tak bergerak" dari Aris Toteles misalnya merupakan contoh dari induktifikasi dari pemikiran sains ke pemikiran agama. Contoh lainnya adalah adanya keteraturan dan keseimbangan yang sangat menakjubkan di dalam alam semesta ini menyimpulkan hukum maha besar yang mengatur.

\section{f. Verivikasi}

Yaitu mengungapkan hasil- hasil penelitian ilmiah yang menunjang dan membuktikan kebenaran-kebenaran (ayat-ayat) al-Qur'an. Misalnya penelitian mengenai potensi madu sebagai obat yang dihubungkan dengan surat an-nahl ayat yang ke 69 (Hanna Djum- hana Bastaman, 1997)

Sementara itu, proses integrasi ilmu dalam penyelenggaraan pendidikan secara filosofis dapat dilakukan dengan bermacam model. Menurut Abuddin Nata, upaya integrasi ilmu dalam penyelenggraaan pendidikan dapat dilakukan dengan tiga model islamisasi pengetahuan, yaitu model purifikasi, modernisasi Islam, dan Neo-modernisme (Bahreisy, 2005) 


\section{a. Model Purifikasi}

Purifikasi bermakna pembersihan atau penyucian. Dengan kata lain, proses Islamisasi berusaha menyelenggarakan pendidikan agar sesuai dengan nilai dan norma Islam secara kaffah, lawan dari berislam yang parsial. Kemudian pula commitment dalam menjaga dan memelihara ajaran dan nilai-nilai Islam dalam segala aspek kehidupan. Adapun empat langkah kerja dari model Islamisasi ini sebagaimana dikembangkan oleh Al-Faruqi dan Al-Attas, meliputi: (a) penguasaan khazanah ilmu pengetahuan muslim, (b) penguasaan khazanah ilmu pengetahuan masa kini, (c) indentifikasi kekurangan-kekurangan ilmu pengetahuan itu dalam kaitannya dengan ideal Islam, dan (d) rekonstruksi ilmu-ilmu itu sehingga menjadi suatu paduan yang selaras dengan wawasan dan ideal Islam.

\section{b. Model Modernisasi Islam}

Modernisasi berarti proses perubahan menurut fitrah atau sunnatullah. Model ini berangkat dari kepedulian terhadap keterbelakangan umat Islam yang disebabkan oleh sempitnya pola pikir dalam memahami agamanya, sehingga sistem pendidikan Islam dan ilmu pengetahuan agama Islam tertinggal jauh dari bangsa non-muslim. Islamisasi disini cenderung mengembangkan pesan Islam dalam proses perubahan sosial, perkembangan IPTEK, adaptif terhadap perkembangan zaman tanpa harus meninggalkan sikap kritis terhadap unsur negatif dan proses modernisasi (Mujib, 2010). Modernisasi berarti berfikir dan bekerja menurut fitrah atau sunnatullah yang hak. Untuk melangkah modern, umat Islam dituntut memahami hukum alam (perintah Allah swt) sebelumnya yang pada giliran berikutnya akan melahirkan ilmu pengetahuan. Modern berarti bersikap ilmiah, rasional, menyadari keterbatasan yang dimiliki dan kebenaran yang didapat bersifat relatif, progresifdinamis, dan senantiasa memiliki semangat untuk maju dan bangun dari keterpurukan dan ketertinggalan.

\section{c. Model Neo-Modernisme}

Model ini berusaha memahami ajaran-ajaran dan nilai-nilai mendasar yang terkandung dalam al-Quran dan al-Hadits dengan mempertimbangkan khazanah intelektual Muslim klasik serta mencermati kesulitan-kesulitan dan kemudahan - kemudahan yang ditawarkan iptek (Gofur, 2010 :48). Islamisasi model ini bertolak dari landasan metodologis,(a) persoalan persoalan kotemporer umat harus dicari penjelasannya dari tradisi, dari hasil ijtihad para ulama terdahulu hingga sunnah yang merupakan hasil penafsiran terhadap al-Quran, (b) bila dalam tradisi tidak ditemukan jawaban yang sesuai dengan kehidupan kotemporer, maka selanjutnya menelaah konteks sosio-historisdari ayat-ayat alQuran yang dijadikan sasaran ijtihad ulama tersebut, (c) melalui telaah historis akan terungkap pesan moral al-Quran sebenarnya yang merupakan etika sosial al-Quran, (d) dari etika sosial al-Quran itu selanjutnya diamati relevansi dengan umat sekarang berdasarkan bantuan hasil studi yang cermat dari ilmu pengetahuan atas persoalan yang dihadapi umat tersebut (Baihaki, 2010) Dari ketiga model Islamisasi di atas, kesemuanya bertujuan untuk memutuskan mata rantai dikotomi ilmu pengetahuan guna menghindari keberlanjutan praktik dikhotomi ilmu ini dalam dunia pendidikan yang berakibat pada terhambatnya kebebasan melakukan penalaran intelektual dan kajian-kajian rasional empirik.

\section{Kesimpulan}

Dari mengenai karakteristik dan model integrasi ilmu madrasah ibtidaiyah dengan ilmu islam Sebagai salah satu jenis satuan pendidikan keagamaan, Madrasah ibtidaiyah tetap mempertahankan ciri khasnya sebagai lembaga pendidikan Islam dengan memberikan mata pelajaran agama ynag paling utama. Adapun dalam karakteristi integrasi ilmu madrasah ibtidaiyah ini memiliki berbagai prinsip dan metode, diantanranya prinsip tersebut Madrasah berusaha mendefinisikan karakter secara komprehensif, didalamnya mencakup berpikir, merasa, dan melakukan Sementara itu, proses integrasi ilmu dalam penyelenggaraan pendidikan secara filosofis dapat dilakukan dengan bermacam model., upaya integrasi ilmu dalam penyelenggraaan pendidikan di madrasah ibtidaiyah dapat dilakukan dengan tiga model islamisasi pengetahuan, yaitu model purifikasi, modernisasi Islam, dan Neo-modernisme. Terjadinya 
dikotomi ilmu pengetahuan Islam dengan ilmu-ilmu umum menyebabkan para ilmuan Islam berusaha melakukan Islamisasi atau integrasi kedua ilmu tersebut, sebab kalau hal ini tidak dilakukan maka akan membawa dampak negatif bagi kehidupan manusia, sehingga dialkaukan berbagai upaya Pendekatan integratif-interkonektif merupakan pendekatan yang tidak saling melumatkan dan peleburan antara keilmuan umum dan agama.

\section{Daftar Pustaka}

Abdullah, M. Amin. 2006. Islamic Studies Di Perguruan Tinggi: Pendekatan IntegratifInterkonektif, Cet. ke-1. Yogyakarta: Penerbit Pustaka Pelajar.

Amirulah Syarbini, 2012. Buku Pintar Pendidikan Karakter, (Panduan Lengkap Mendidik Karakter Anak di Sekolah, Madrasah dan Rumah).

Bahreisy, Salim. 2005. Ilmu Pendidikan Islam. Bina Ilmu. Surabaya

Baihaki. Ahmad. 2010. Ilmu Pendidikan Islam. Grafindo Presada Media Group. Jakarta.

Bisri, Muhammad. 1995. Menuju Sistem Pendidikan Integralistik. Gema Clipping Service.

Bastaman, Hanna Djumhana, 1997. Integrasi Psikologi dengan Islam, Yogyakarta: Pustaka Pelajar.

Haedar Nashir, 2013. Pendidikan Karakter Berbasis Agama dan Budaya, Yogyakarta: Peresindo Multi

Gofur. Abdul. 2010. Ilmu Pendidikan Islam. Insan Media Group. Jakarta

Kuntowijoyo. 2005. Islam Sebagai Ilmu, Cet. Ke-2. Jakarta: Penerbit Teraju.

Mas'ud. Abdurrahman . 2003. Menggagas Format Pendidikan Nondikotomik. Gama Media. Yogyakarta.

Mujib. Abdul. 2010. Ilmu Pendidikan Islam. Kencana Prenada Media Group. Jakarta.

Novan Ardy Wiyani dan Barnawi,2012. Ilmu Pendidikan Islam, Jogjakarta: Ar Ruzz Media.

Rahman Fazlur. 1992. Islam and Modernity. Chicago: University of Chicago 